\title{
Fırçasız DC Motorunun Eksen Kaçıkığgı ve Kırık Mıknatıs Arızalarının Tespitinin Bilgisayar Benzetimi ile Yapılması
}

\author{
Mehmet Recep MINAZ* \\ Siirt Üniversitesi, Elektrik-Elektronik Mühendisliği, Siirt \\ (ORCID: 0000-0001-8046-6465)
}

\begin{abstract}
$\ddot{\mathbf{O} z}$
$\mathrm{Bu}$ çalışma firçasız DC motorlarda (BLDC) oluşabilecek arızalar önceden belirlenerek motor çalışmasının devamlılığının sağlanması ve oluşabilecek olumsuzlukları önlemek açısından önem taşımaktadır. Hem arıza tespiti ve arıza şiddetinin belirlenmesi hem de sabit mıknatıslı motorunun tasarımı sonlu elemanlar yöntemi kullanılarak gerçekleştirildi. Sonlu elemanlar yöntemi kullanılarak motor analizleri yapıldı. Sonlu elemanlar yöntemiyle sağlıklı motor, arızalı motor ve bu arızaların farklı şiddetlerinde simülasyonlar gerçekleştirildi. Endüksiyon motoru için Hızlı Fourier Dönüşümü (FFT) uygun görülürken BLDC motoru için trapezoidal sinyal çıkışından dolayı Dalgacık dönüşüm (WT) yöntemi kullanılarak analiz gerçekleştirilmiştir. Bu çalışmada daha az belirgin olmayan durum analiz edilmiştir. FFT ve WT ölçülenler ile iyi bir uyum içinde olduğunu göstermiştir. Önerilen yöntemi kullanarak stator akımı ve stator geriliminin sabit mıknatıs arıza tespiti için yararlı olduğunu göstermiştir. Ayrıca, farklı sınıflandırıcılar kullanarak karşılaştırma yapılmıştır. İncelenen k-NN, MLP ve RF algoritması sınıflandırma da doğruluğunun oldukça kayda değer olduğu bulunmuştur.
\end{abstract}

Anahtar kelimeler: Fırçasız DC motor, sinyal işleme, arıza tespiti.

\section{Broken Rotor Magnet and Eccentricity Faults Detection of Brushless DC Motor Simulation Model}

\begin{abstract}
This study is important in order to ensure the continuity of the motor operation by preventing faults that may occur in brushless DC motors (BLDC) and to prevent possible negativities. Both the detection of the fault and the determination of the severity of the fault and the design of the permanent magnet motor were carried out using the finite element method. Motor analysis was performed using finite element method. Simulations of healthy motor, defective motor and different severities of these faults were performed by finite element method. While Fast Fourier Transform (FFT) was found suitable for induction motor, wavelet transform (WT) method was used for BLDC motor because of trapezoidal signal output. This study was less pronounced in the non-state analysis. FFT and WT were in good agreement with those measured. Using the proposed method, it has shown that stator current and stator voltage are useful for permanent magnet fault detection. In addition, comparisons were made using different classifiers. The accuracy of the k-NN, MLP and RF arguments used was found to be quite significant.
\end{abstract}

Keywords: Brushless DC motor, signal processing, fault detection.

\section{Giriş}

Fırçasız doğru akım motorları (BLDC) son yıllarda endüstride büyük avantajlar sağlaması nedeniyle araştırmacıların dikkatini çekmiştir. BLDC motorlar verimliliklerinin yüksek olması, yüksek güç faktörüne sahip olması ve daha az bakıma ihtiyaç duyması gibi avantajlara sahiptir [1]. Rotorunda sargılar yerine sabit mıknatıslar yerleştirilmektedir. Bu makinayı ayırt eden en önemli ve karakteristik özelliği de rotorunda sargı bulunmamasıdır. Sargıların işlevini gören rotor mıknatısları sayesinde motor kayıplarının azalmasının yanı sıra ağırlık ve hacminin de azalması sağlanmıştır. Böylece aynı güçte olan

"Sorumlu yazar: recminaz@gmail.com

Geliş Tarihi: 24.07.2019, Kabul Tarihi: 06.12.2019 
makinalara göre daha avantajlıdır. Sürücü sistemi olmadan sürülemeyen bu motorlarda hassas hız ve konum kontrolü yapıldığından motorun sağlıklı çalışması oldukça önemlidir. Motordaki herhangi bir arızanın motorun hassasiyetini etkilemesi söz konusu olduğundan, arıza tespitinin önceden yapılması bu motorlarda önemlidir [2,3]. Sabit mıknatıslardaki önemli gelişmeler sabit mıknatısın elektrikli makinelerde kullanılmasını sağlamıştır. Konvansiyonel DC motorların rotorundaki konvansiyonel alan sargılarının sabit mıknatıs ile değiştirilmesi ile alan devresi bakır kayıplarını daha da azaltılması ve net verimlerini arttırdı. Bu sabit mıknatıslı makineleri, yüksek verimlilik, yüksek tork yoğunluğu, esnek tasarım kompakt boyutu ve yüksek dinamik performans nedeniyle çeşitli endüstriyel uygulamalarda yaygın olarak kullanılır hale geldi [4,5]. Karmaşık çalışma koşulları, dar montaj alanı ve zayıf ısı yayma ortamı nedeniyle, BLDC motorlar üç ana kategoriye ayrılabilecek yüksek bir arıza olasıllğına sahiptir: stator arızası, rotor arızası ve yatak arızası dinamik eksantriklik arızası (DEF) bir tür mekanik arızadır [6]. Hava boşluğundaki dengesizliğin artmasından dolayı mekanik ve elektromanyetik titreşimlere neden olmaktadır [7]. Demagnetizasyon arızası hava boşluğu akı dağılımını bozar. Bozulan bu akı dağılım bozukluğu dengesiz manyetik çekime ve akım harmoniklerine neden olur. Buda titreşim ve akustik gürültü oluşturur. Ayrıca rulmanların zorlanmasına neden olabilir. Bazı durumlarda, Sürekli mıknatıs parçalar halinde kırılır ve hava boşluğuna düşer stator sargılarına da zarar verebilir [8]. BLDC motorlarda arıza tespiti için literatürde birçok farklı yöntem önerilmektedir. Arıza tespiti yapılırken motordan alınan akım, gerilim, manyetik akı, sıcaklık, titreşim, akustik sesler, moment gibi bazı veriler kullanılmaktadır. $\mathrm{Bu}$ yöntemler içerisinde arıza tespitinde çok sayıda başarılı olan yöntemler bulunmaktadir.

Motor akım sinyal analizi (MCSA) gibi, arıza tespitinde oldukça popülerlik kazanmıştır ve motorun çalışma sırasındaki durumunu izlemek için birçok araştırmacı tarafindan yaygın olarak kullanılmaktadır. Arıza tespitinin motor faz akımları üzerindeki etkisini incelemek amacıyla MCSA analizinde, Hilber-Huang (HHT) [8], dalgacık dönüşümü (WT) [9] ve en yaygın olarak hızlı Fourier dönüşümü (FFT) [10] gibi sayısız sinyal işleme tekniği kullanılmıştır. Günümüzde, FFT, özellikle sabit çalışma koşullarında, elektrik motorlarında arıza tespiti için en yaygın yöntem haline gelmiştir. FFT'nin başarısız olduğu konu, sabit olmayan bir durumda, yani zamanla değişen sinyallerde uygulamalara yönelik kısıtlamasıdır. Rosero ve arkadaşları [10] ile Lee ve arkadaşları [11] tarafindan yapılan çalışmada vektör kontrol invertörüne sahip sabit mıknatıslı bir dq-ekseni çerçevesi ile senkronize olduğundan ve normal olarak bir sabit mıknatıslı motoru kontrol etmek için kullanıldığından q-ekseni akımının ikinci harmoniğinin değişimi bu şekilde kolayca izlenebilir. Sabit mıknatıslı dq eksen takımı çerçevesindeki q ekseni akımındaki ikinci harmoniği stator kısa devre arızasının veya bir invertör açık anahtar arızasının göstergesi olarak kullanılabilir. Ebrahimi ve arkadaşları [12] ile Stavrou ve arkadaşları [13] bazı basit frekans analizine dayalı arıza tespit teknikleri ve yüksek frekanslı harmonik karşılaştırması kullanılmıştır. Her ne kadar MCSA ve harmonik karşılaştırması tabanlı arıza tespit teknikleri etkili olmasa da, nispeten basit ve motora kolayca uygulanabilirdir. Bununla birlikte, bu yöntemlerin tüm çalışma koşullarında kesin bir önceden tanımlanmış referans arıza eşik seviyesine ihtiyacı vardır; bu, yalnızca makineyle ilgili tüm veriler mevcut olduğunda elde edilebilir. Bugüne kadar, MCSA'da, PMSM için tatmin edici bir doğruluk seviyesine sahip hiçbir arıza modeli önerilmemiştir; Eğer doğru bir arıza eşiği tanımlanabilirse, yukarıda belirtilen yöntemler son derece yararlı olabilmektedir. $\mathrm{Bu}$ çalışmada manyetik giderme işlemi, dinamik ve statik eksenden kaçıklık arızasını oluşturan faktörler ele alınarak bu fenomenlerin nedenleri ve arıza şiddetine göre makine performansı üzerindeki etkileri durağan olan koşullar altında (tam yüklenme durumunda ve sabit hızda) arıza teşhisi için önerilen teknikler uygulanmıştır. Elde edilen sinyaller makine öğrenmesi metotlarından k-NN, MLP ve RT algoritması ile başarıyla arızanın tespitinin yapılabildiği gösterilmiştir.

\section{Materyal ve Metot}

\subsection{Sonlu Elemanlar Yöntemi}

Tasarımı gerçekleştirilen BLDC motorun özellikler Tablo 1'de verilmiştir. Yapısal tasarımı tamamlanan sürekli mıknatıslı makine sonlu elemanlar yöntemi kullanılarak analiz edilmiştir. Manyetik alan analizinde, yeni tasarlanan bir elektrik makinesinin çalışma davranışlarının analizinde, tork ve moment analizlerinin gerçekleştirirken sonlu elemanlar yöntemini çok sık kullanmaktadır. 1940 yılında önerilen bu analiz yöntemi, birçok mühendislik tasarımında, modelleme ve imalat süreç tespitinde de 
kullanılmıştır. Sonlu elemanlar yöntemi elektrik mühendisliğinde ise 1970'li yıllarda manyetik devrelere uygulanmaya başlamıştır. Sonlu elemanlar yöntemi kullanılarak yapılan ilk çalışma, Silvester tarafindan doyumlu manyetik alan problemlerinin analizidir. Chari ve Silvester tarafindan, 1971 yılında doğrusal olmayan varyasyon formüllerinin çözümü ile elektrik makinelerinde elektro manyetik alan hesaplanmıştır. Bir elektrik makinesinin taslak aşamasındaki, hareketli ve durgun konumlarındaki analizleri Sonlu elemanlar yöntemi kullanılarak gerçekleştirilebilir. Bu yöntem özellikle bir elektrik makinesinin tasarım aşamalarının kullanılmaktadır. Ayrıca bir motorun boşta veya yük şartları altında üretebileceği akı ve moment analizleri, tasarımı planlanan motorun fiziksel boyutları ve malzeme cinsi gibi özellikler üzerinde değişiklikler yaparak, mühendislik tasarımına en uygun davranış sergileyen motor ve generatör tipleri tespit edilebilmektedir.

$\mathrm{Bu}$ yöntemin kullanılması, imalat öncesindeki model tasarım maliyetlerinin azalmasını sağlamaktadır. Ayrıca kontrol ve tasarım teknolojisinin kusursuz bir şekilde tasarlanmasını sağlamaktadır. $\mathrm{Bu}$ yöntem elektrik makinesi tasarımı ile ilgili literatür araştırmalarında geniş yer bulmaktadır. Motor veya generatör iki şekilde tasarlanmaktadır. Birinci yöntem, bir eşdeğer devre oluşturmak için genel elektrik makine teorisi kullanmak, diğer yöntem ise; sayısal incelemeler yapılmak suretiyle manyetik alan dağılımının tespit edilmesidir. Eşdeğer devreler veya analitik tasarımda motorda basitleştirme varsayımı kullanılmaktadır. Basitleştirilen varsayımlarda doğrusal eksenli manyetik malzemeler, diş-oluk rotor-stator geometrileri şeklinde, en uygun varsayılan bir geometri ve makine sargılarının kompozisyonudur. Sayısal analiz yöntemlerinden biri ve en önemlisi olan sonlu elemanlar yöntemi ile en uygun alan dağılımı, geometrik detaylar, manyetik elemanların doğrusal olmayan geçirgenlikleri hesaba katılarak en uygun tasarım yapılabilmektedir. Akademik çalışmalar neticesinde özellikle son zamanlarda sonlu elemanlar yöntemi verilerinin elektrik makinaların kullanılmaya başlaması ve olumlu sonuçların elektriksel analiz araştırmalarına yön verdiği bilinmektedir $[14,15]$.

Tablo 1. BLDC motoruna ait tasarım parametreleri

\begin{tabular}{lcl}
\hline Makine kutup sayısı & 28 & adet \\
\hline Stator Diş Çapı & 270 & $\mathrm{~mm}$ \\
Stator İç Çapı & 160 & $\mathrm{~mm}$ \\
Rotor Diş Çapı & 159 & $\mathrm{~mm}$ \\
Rotor İç Çapı & 61 & $\mathrm{~mm}$ \\
Stator oluk Sayısı & 72 & adet \\
Anma Gerilimi & 48 & $\mathrm{~V}$ \\
Giriş Gücü & 1500 & $\mathrm{~W}$ \\
Anma Hızı & 380 & $\mathrm{rpm}$ \\
Anma Torku & 36.16 & $\mathrm{Nm}$ \\
Anma Akımı & 31.62 & $\mathrm{~A}(\mathrm{RMS})$ \\
Atalet Momenti & 0.227 & $\mathrm{kgm} 2$ \\
\hline
\end{tabular}

\subsection{Arıza Tespitinde Kullanılan Teknikler}

Gelişen bilgisayar teknolojileri ile birlikte her geçen gün kullanılmakta olan veri miktarı da hızla büyümekte; hızla artan veri miktarı da bu verilerin analiz edilmesini zorlaştırmaktadır. Bir tahmine göre her 20 ayda bir dünyadaki veri miktarının ikiye katlandığı ifade edilmektedir. Uygun sinyal işleme aracını kullanarak bir sinyalden bilgi edinmek, ardından uygun veri madenciliği tekniği, motor durumunu doğru şekilde belirtmek arızanın ekken teşhisi için oldukça önemlidir [16, 17]

Weka, Waikato Üniversitesi'nin ürünüdür ve ilk olarak 1997 yılında modern haliyle uygulanmıştır. $\mathrm{Bu}$ makine öğrenme paketi, halka açıktır ve gerçek dünyadaki veri madenciliği sorunlarını çözmek için bir algoritmalar koleksiyonu sunar. Weka'daki birincil öğrenme yöntemleri sınıflandırıcılardır. Verileri modelleyen bir kural kümesi veya karar ağacı oluştururlar. Weka ayrıca kurallarını ve kümelenme verilerini öğrenmek için algoritmalar da içerir. Tüm uygulamalarda tek biçimli bir komut satırı ara yüzü vardır. Ortak bir değerlendirme modülü, belirli bir veri setine göre birkaç öğrenme algoritmasının göreceli performansını ölçer [18]. WEKA, ham verinin işlenmesi, ögrenme metotlarının veri üzerinde istatistiksel olarak değerlendirilmesi, ham verinin ve ham veriden öğrenilerek çıkarılan modelin görsel olarak izlenmesi gibi veri madenciliğinin tüm basamaklarını destekler. Geniş bir öğrenme algoritmaları yelpazesine sahip olduğu gibi pek çok veri önişleme filtreleri içerir. 
Bu çalışmada Weka programı ile arızaların şiddetini test etmede yapay sinir ağları(MLP), k-en yakın komşu(kNN) ve karar ağaçları (Random Tree) sınıflandırma yöntemleri olarak seçilmiş ve doğruluk yüzdesi açısından uygun görülmüştür. kullanılan tüm sınıflandırıcı algoritmalar doğruluk oranları ve işlem süreleri farklılık gösterse bile benzer mantıkla çalışmaktadır. Çalışmada farklı arıza şiddetlerine bağlı akımların spektral analizi sonucu ile elde edilen harmonik genlikleri giriş verileri olarak arıza tespiti eğitiminde kullanılmıştır. Her bir arızaya ait 100 harmonik akım sinyaline FFT uygulanarak elde edilmiş ve bu 100 harmonik genliği ile yapılan sınıflandırıcı algoritmalarda 101 adet harmonik girişi ve 15 adet farklı şiddetlerde arıza çıkışları vardır. Aynı arıza imzası eğitim, test ve doğrulama verisi olarak kullanılarak eğitilen makina öğrenme algoritmalarının doğruluk tahminleri ortaya koyulmuştur.

\subsection{Demagnetizasyon ve Eksenden Kaçıklık Arızası}

Mıknatısların tamamen manyetikten arındırılması, çalışma sıcaklıkları Curie sıcaklığından yüksek olduğunda gerçekleşebilir. Bununla birlikte, mıknatıslardaki Curie sıcaklığı o kadar yüksektir ki, bu tür bir manyetik giderme işlemi yapılması olağandışıdır. Bununla birlikte, kısmi manyetik giderme, mıknatısların çalışma noktası manyetik giderme dizinin altına düştüğünde de olabilir [19, 20]. Sicaklığın manyetik kalıntı üzerindeki etkisi, denklemde ifade edilen Curie sıcaklığının altında yaklaşık olarak doğrusaldır.

$B_{r}(T)=B_{r}\left(T_{0}\right)\left[1+\Delta_{B}\left(T-T_{0}\right)\right]$

T mıknatısın çalışma sıcaklığı, $T_{0}$ tercih edilen sıcaklık $\operatorname{Br}\left(T_{0}\right)$ şu anda $T_{0}$, ve $\Delta_{B}$ negatif bir sayı olan tersinir sicaklık katsayisidır [21].

Bir BLDC statoru ile ilişkili diğer arızalar arasında, literatürde bildirilen en yaygın tür, StatorTur kısa devre olarak adlandırılan, BLDC'nin stator sargı dönüşleri arasındaki yalıtım yetersizliğinden kaynaklanmaktadır [22]. Bu yalıtım arızası sonucu motor isınmakta ve doğrudan olmasa da dolaylı yoldan yukarıda açıklandığı gibi Demagnetizasyon etki yaratmaktadır. Görüldüğü gibi bir arızanın oluşumu beraberinde diğer bir arızayı doğurmaktadır. Bu çalışmada bu iki durumundan farklı 2. yöntem olarak mıknatısın kalınlık parametresi değiştirilerek, mıknatısta oluşan çatlaklar ve kopmalar göz önüne alınmış motorun geometrik yapısındaki akı dağılımı ve akım- tork sinyallerine olan etkileri Demagnetizasyon arızası altında incelenmiştir.

Bir rotorun hareketi eş merkezli, statik ve dinamik eksantrik hareketler olarak sınıflandırılabilir. İdeal bir eş merkezli hareket durumunda, rotor, stator merkezine göre konsantrik olarak döner ve rotor merkezi stator merkezine çakıştığından üniform bir hava boşluğuna sahiptir. Statik eksantrik hareketinde, rotor merkezinin etrafinda döner ve hava boşluğu tekdüze değildir, ancak değişmez [23]. Eksantriklik büyük olduğunda, ortaya çıkan dengesiz radyal kuvvetler statordan rotora sürtünmeye neden olabilir ve bu durum stator ve rotora zarar verebilir [24]. Motorun ileri boyutta hata genleşmesini önlemek için eksantrik arızasının oluşumunu tam olarak tespit etmelidir.

Bir BLDC motor, bir tür senkron motordur. Bu, stator tarafından oluşturulan manyetik alanın ve sabit mıknatıslı rotorun manyetik alanının senkron olarak döndüğü anlamına gelir. BLDC motorları farklı sayıda faz konfigürasyonuna sahiptir. Bunlardan, 3-fazlı motorlar birçok uygulamada en popüler olanlardır. Bu çalışmada; 3-fazlı, sürekli mıknatıslı dış rotorlu BLDC arıza teşhis teknikleri uygulanmak üzere sonlu elemanlar yöntemi ile tasarlanmıştır.

Kullanılan simülasyon programı, Maxwell' in denklemlerini sonlu bir uzayda bulunan bölgede problemlerini çözerken elektromanyetik problemleri çözmek için sonlu elemanlar analizi kullanılmıştır. Sonlu elemanlar yöntemli yazılımlar, tasarlanacak elektrik motoru, transformatör gibi elektrik makinelerinin davranışlarının modellenebilmesini sağlamaktadır. Böylece çok sayıda prototip model oluşturulmasına gerek kalmadan değişik geometrilere ve özelliklere sahip makinelerin hızlı bir şekilde analiz edilmesine olanak vermektedir. 


\section{Bulgular ve Tartışma}

\subsection{Demagnetizasyon Arızası}

Sonlu elemanlar yöntemi kullanılarak, gerçek bir sürekli mıknatıslı BLDC motorun özelliklerine dayanarak tasarlanan bu sağlam motor üzerinden on dört tane arızalı motor modeli oluşturuldu. Tüm simülasyonlar 0.0001 saniye adım aralıkla 0.2 sn boyunca 2000 adımda gerçekleştirilmiştir. Bunun ardından zaman domenin de elde edilen akım sinyaline FFT uygulanarak, yüz örnekleme frekansı elde edilip spektral analizi gerçekleştirilmiştir. FFT analizi motorun akım sinyaline 114.5 sn ile $123.5 \mathrm{sn}$ aralıklarında tam bir dalga boyu için uygulanmıştır. Bu frekans analiz yöntemi tek periyot ve çoklu frekans fikrine dayanmaktadır. Elde edilen çıkış sinyali sinüs ve kosinüslerin toplamı olarak ifade edilir. Analiz sonucu temel frekans ve bunların katları olmak üzere $\mathrm{dB}$ cinsinden yüz çıkış harmoniği elde edildi. Referans alınan aralık tüm arızalı motor modelleri için aynı alınarak sinyallerin arızalara ve arıza şiddetlerinin artışına karşı gösterilen değişimlere bakıldı ve sağlıklı motor ile arızalı motorların sergilediği davranışlar karşılaştırılmıştır.

Arıza teşhisi açısından, manyetik giderme hatası, yerel ve düzgün manyetikleştirme işlemine ayrılabilir. Tek tip manyetik giderme, makinedeki mevcut tüm sabitmıknatısların aynı seviye ve desende manyetikleştirilmemesi durumunda oluşur. Bütün mıknatıslarda oluşturulan inceltme durumu geri dönüşümsüz manyetik gidermeye örnek gösterilebilir. Mevcut asimetri nedeniyle makinede yerel manyetik giderme tespiti daha kolaydır. Yukardaki farklı arıza şiddetlerine ait akı dağılımlarından da görüldüğü gibi mıknatıs inceldikçe manyetik akı etkisi düşmektedir. Bununla beraber faz akımlarında yükselme olurken verimde düşüşe gittiği gözlemlenmiştir. Ancak bu bulgular arasındaki farkalar oldukça küçük olduğundan kestirim için uygun giriş değerleri olarak kabul edilemez. Bu ham verilerin çözünürlüğü artırmak için spektral analiz ile işlenmiş veri elde etmek için bir uygun ve geçerliliğini koruyan bir yaklaşımdır. Stator giriş akım sinyaline FFT uygulanarak rotor-arıza frekansları daha sonra mevcut spektrumdan tanımlanır ve hatanın ciddiyetini tespit etmek için izlenir.

Miknatıs kusuru olarak mekanik darbeler sonucu oluşan mıknatıs kırık ve kopmaları ele alınmıştır. Şekil 1'de modelde kısmi manyetik giderme hatası oluşturmak için mıknatıslardan birinde(mag_4) \%12, \%6, \%9, \%3 oranlarında kopmalar gerçekleştirilerek arıza şiddetlerinin motor üzerindeki etkileri analiz edildi.

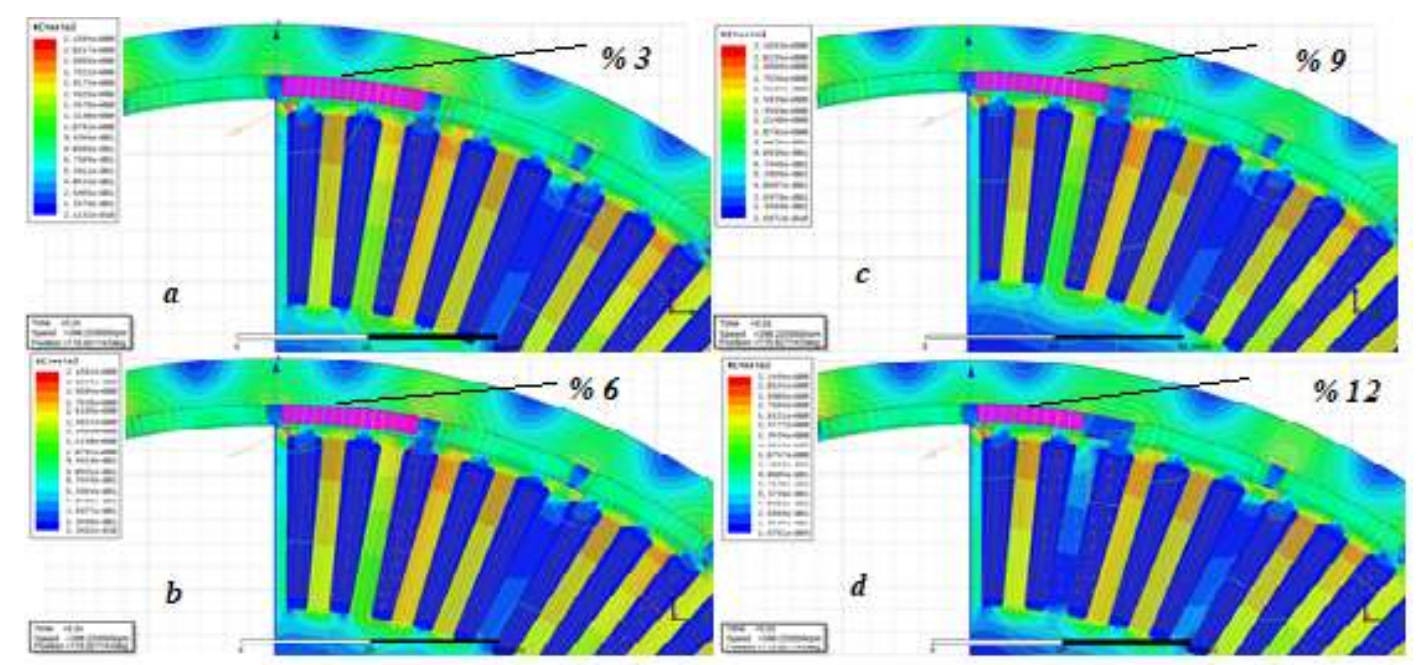

Şekil 1. a) \%3 kırık mıknatıs kusuru b) \%6 kırık mıknatıs kusuru c) \%9 kırık mıknatıs kusuru d)\%12 kırık miknatıs kusuru.

Mıknatısta oluşturulan kırılmalar sonucu iki mıknatıs arasındaki açıklık kopma şiddeti ile doğru orantılı olarak artar. Modellemelerden de görüldüğü gibi mıknatıslar arasındaki açıklık artığında manyetik akı yoğunluğunun azaldığı görülmektedir. Motorun sağlam durumda mıknatıs parametreleri ve fiziksel yapıları aynı iken oluşturulan kırık mıknatıs arızaları sonrası makine artık simetrik değildir ve hava aralığı manyetik akısı aynı değildir. Bu çalışmada kullanılan sürekli mıknatıs özellikleri Tablo 2'de verilmiştir. 
Tablo 2. NdFe35_2DSF1 sürekli miknatıs parametreleri

\begin{tabular}{lcl}
\hline Relative permeability & 1.0998 & adet \\
\hline Bulk conductivity & 625,000 & $\mathrm{~S} / \mathrm{m}$ \\
Magnetic coercivity & Vektor & $\mathrm{mm}$ \\
H magnitude & 890.000 & $\mathrm{~A} / \mathrm{m}$ \\
Maximum working tempt & 100 & ${ }^{\circ} \mathrm{C}$ \\
\hline
\end{tabular}

Kurulum sırasında kalıcı mıknatıslar mekanik basınca maruz kalır bunun yanında yüksek hızlarda ve aşırı yüklenme durumlarında parçalanmaya yol açabilecek küçük çatlaklara neden olabilir. Zamanla bu çatlak mıknatıslar koparak hava aralığına düşer ve beraberinde yeni arızalar oluşturur. $\mathrm{Bu}$ kırık mıknatıslar tork sinyallerindeki bozulmalar oldukça belirgindir. Şekil 2'de kırık mıknatısların tork sinyali verilmiştir.

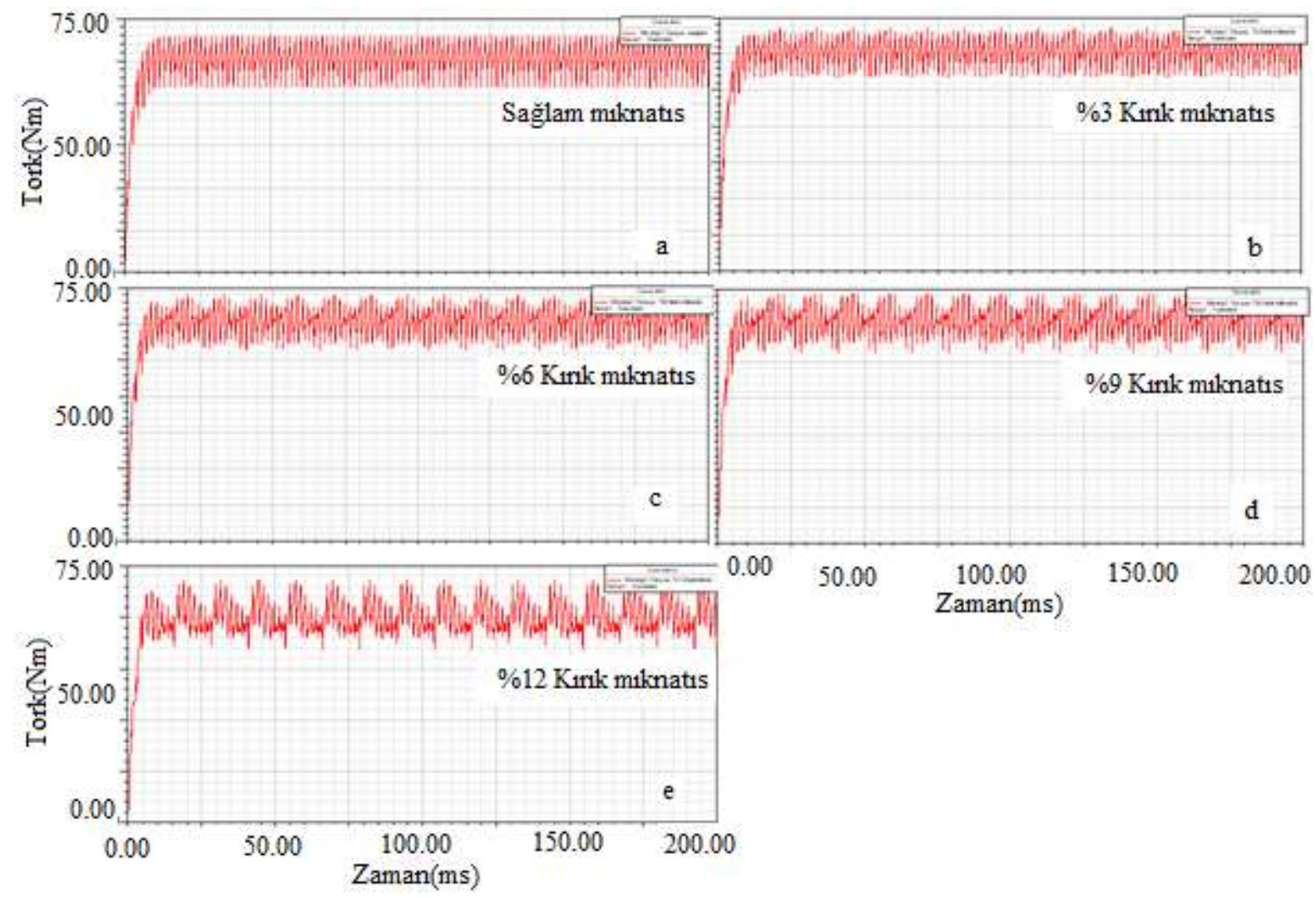

Şekil 1. Kırık mıknatıs tork dalgalanma spektrumları. a)sağlam motor b) \%3 kırık mıknatıs c) \%6 kırık mıknatıs d) $\% 9$ kırık mıknatıs e) $\% 12$ kırık mıknatıs 


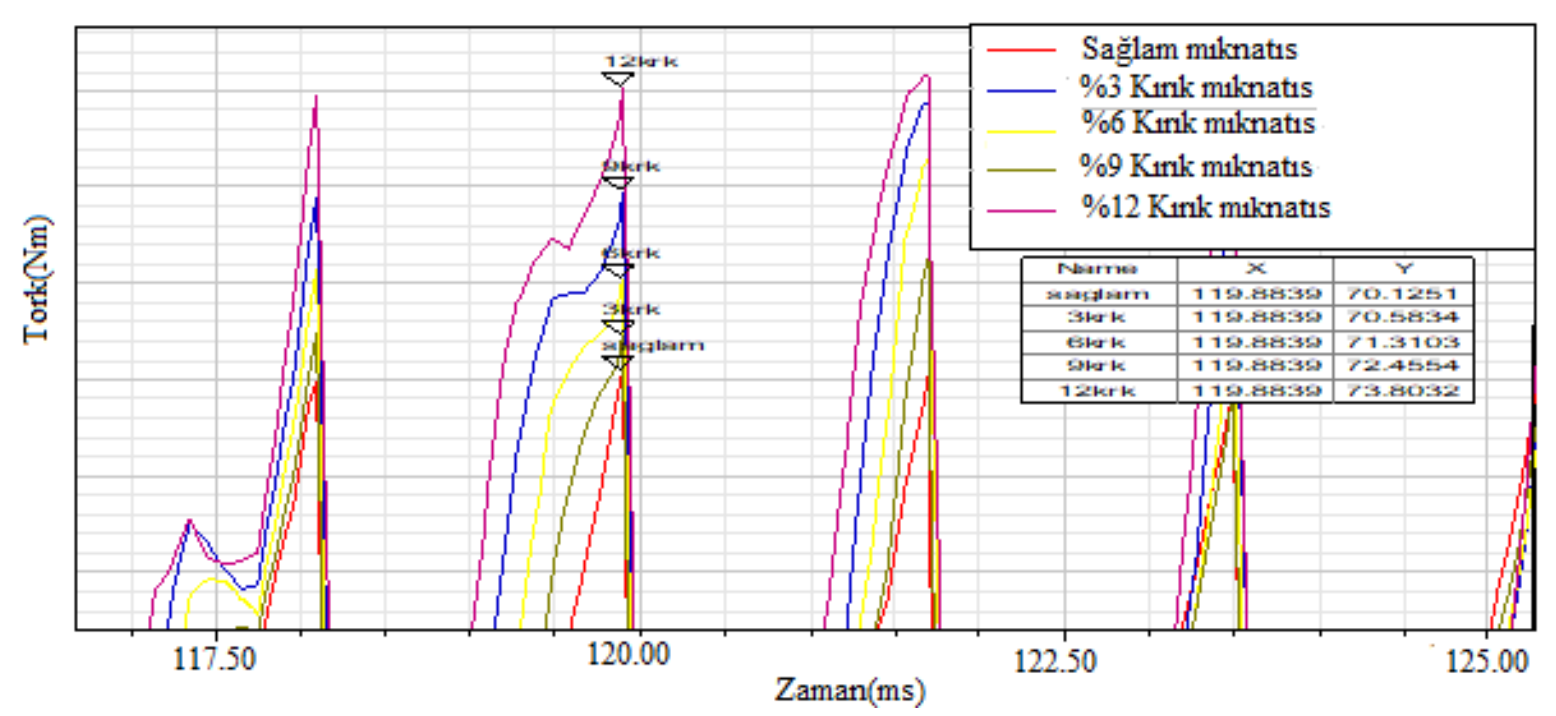

Şekil 3. Farklı mıknatıs kalınlık değerleri için çözünürlüğü artırılmış elektromanyetik tork dalga formları

Şekil 3'te sunulan sonuçları incelerken, mıknatıs kalınlığının genişlemesinin makinenin performansı üzerinde önemli bir etkisi olduğu görülebilir.

Tablo 1. Farklı şiddetteki kırık mıknatısların akım ve tork karşılaştııılması

\begin{tabular}{|c|c|c|}
\hline & Max Faz akımı & Max Tork \\
\hline Sağlıklı & $81.4089 \mathrm{~A}$ & $70.1251 \mathrm{Nm}$ \\
\hline$\% 3$ kırık & $84.4146 \mathrm{~A}$ & $70.6834 \mathrm{Nm}$ \\
\hline$\% 6$ kırık & $87.8188 \mathrm{~A}$ & $71.3103 \mathrm{Nm}$ \\
\hline$\% 9$ kırık & $91.5134 \mathrm{~A}$ & $72.4554 \mathrm{Nm}$ \\
\hline$\% 12$ kırık & $95.3660 \mathrm{~A}$ & $73.8032 \mathrm{Nm}$ \\
\hline \hline
\end{tabular}

Tablo 3 te görüldüğü gibi akım ve tork dalga formları artarken gerilim ve verimde düşüşler gerçekleşmiştir. Dengesiz manyetik çekmeden dolayı bu arızanın şiddeti artıkça diğer rotor arızalarını tetikler ve bunun yanında titreşim ve gürültüye sebep olur.

\subsection{Eksenden Kaçıklık Arızası}

Hava boşluğundaki düzensiz manyetik alan dengesiz manyetik kuvvetler oluşturur. Eksantriklik ayrıca bir rotorun devir merkezine göre dengesizliğini arttırır ve eş zamanlı olarak merkezkaç kuvveti oluşturur. Dengesiz manyetik kuvvet ve merkezkaç kuvveti yatağı periyodik olarak uyarır ve yatağın yük kapasitesini aştığında dinamik eksantrik hareket gelişebilir. Sonunda, yatak arızalarına neden olabilir çünkü yatak, motorun en esnek ve savunmasız bileşenidir [25]. BLDC motorlarda statik, dinamik ve karma eksantriklikler, bir mil yatağı tarafindan oluşturulabilir. Çalışmada kullanılan dış rotorlu motorda rotor iç çapı ile stator dış çapı arasında bir hava aralığı mevcuttur. Rotor şaft ve stator belirli bir değere kadar kaydırılabilir. Rotorun stator merkezinden kaydırılıp kendi etrafinda döndürülmesi ile oluşturulan arıza Statik Eksantriklik arızası olarak bilinir. Bunun yanında rotorun stator merkezinden kaydırılıp stator merkezi etrafinda döndürülmesi ile Dinamik Eksantriklik oluşturulabilir. Bu iki eksantriklik arızanın birleşmesi ile hibrit eksantriklik oluşturulabilir. Bu çalışmada bu durumların 3'ü de incelenmiştir.

Dinamik eksantriklik(DE) durumu için rotor ve üzerindeki sabit mıknatıslar stator merkezinden $0.3 \mathrm{~mm}, 0.25 \mathrm{~mm}, 0.2 \mathrm{~mm}$ ve $0.15 \mathrm{~mm}$ kaydırılarak oluşturulmuştur. Motorun $2 \mathrm{~mm}$ hava aralığ 1 referans alınarak arıza şiddeti belirlenmiştir. $2 \mathrm{~mm} \% 100$ eksentriklik olarak referans alındığında $0.3: \% 15,0.25$ : \%12.5, 0.2: \%10 ve 0.15: \%7.5 eksantriklik olarak arıza şiddetleri belirlenmiştir. Maximum kaydırılma oranın $0.35 \mathrm{~mm}$ olduğu tespit edilmiştir. Sağlıklı ve hatalı BLDC motorun Şekil 4 ve Şekil 5 'te stator akımı ve tork sinyalleri zaman düzleminde gösterilmiştir. 


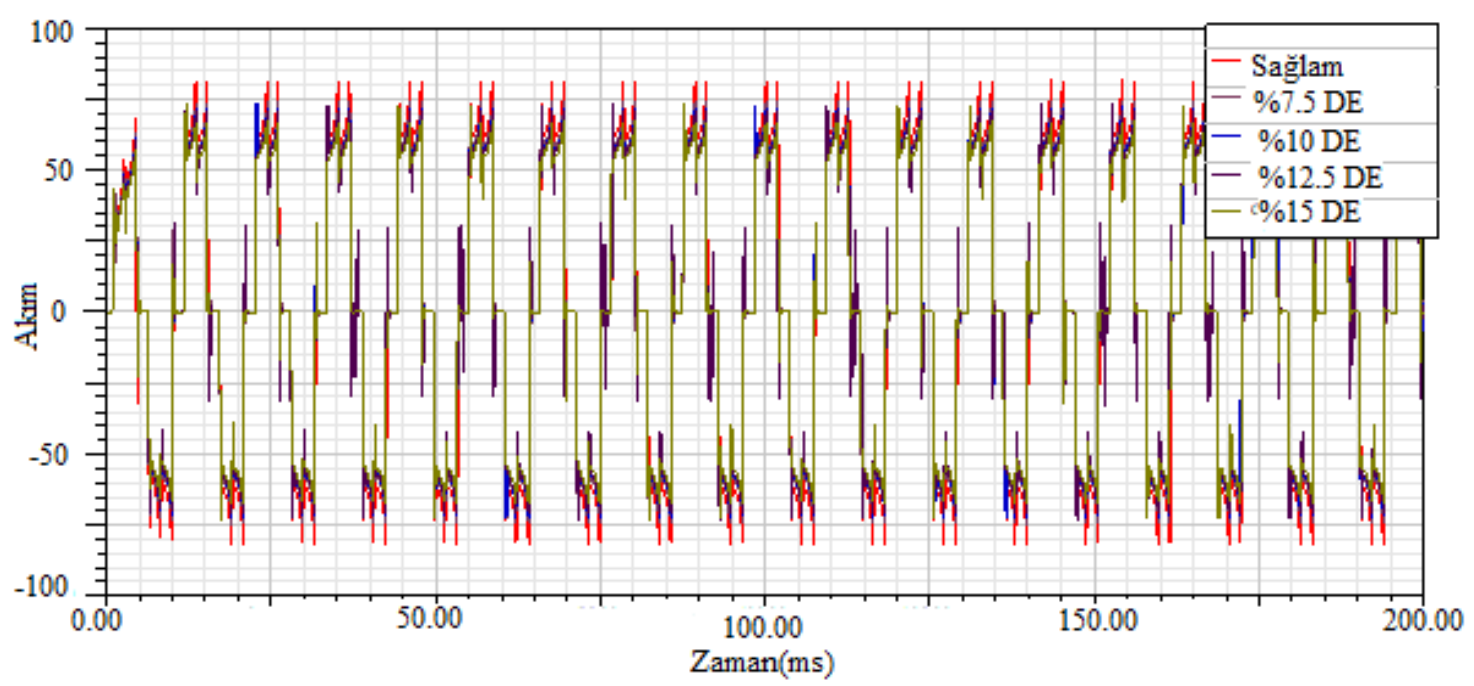

Şekil 4. Farklı dinamik DE şiddetlerinin üst üste bindirilmiş akım dalga formları

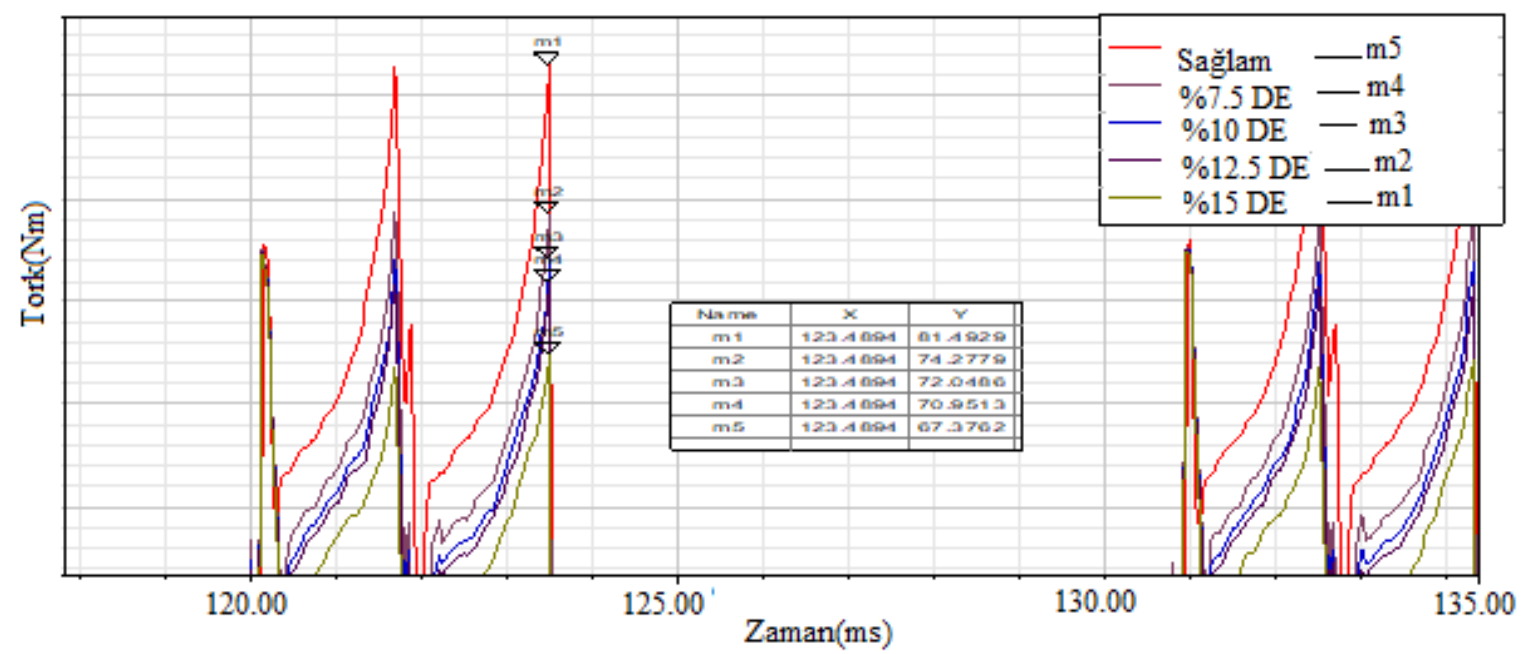

Şekil 5. Çözünürlüğü artırılmış farklı DE şiddetlerinin üst üste bindirilmiş akım dalga formları

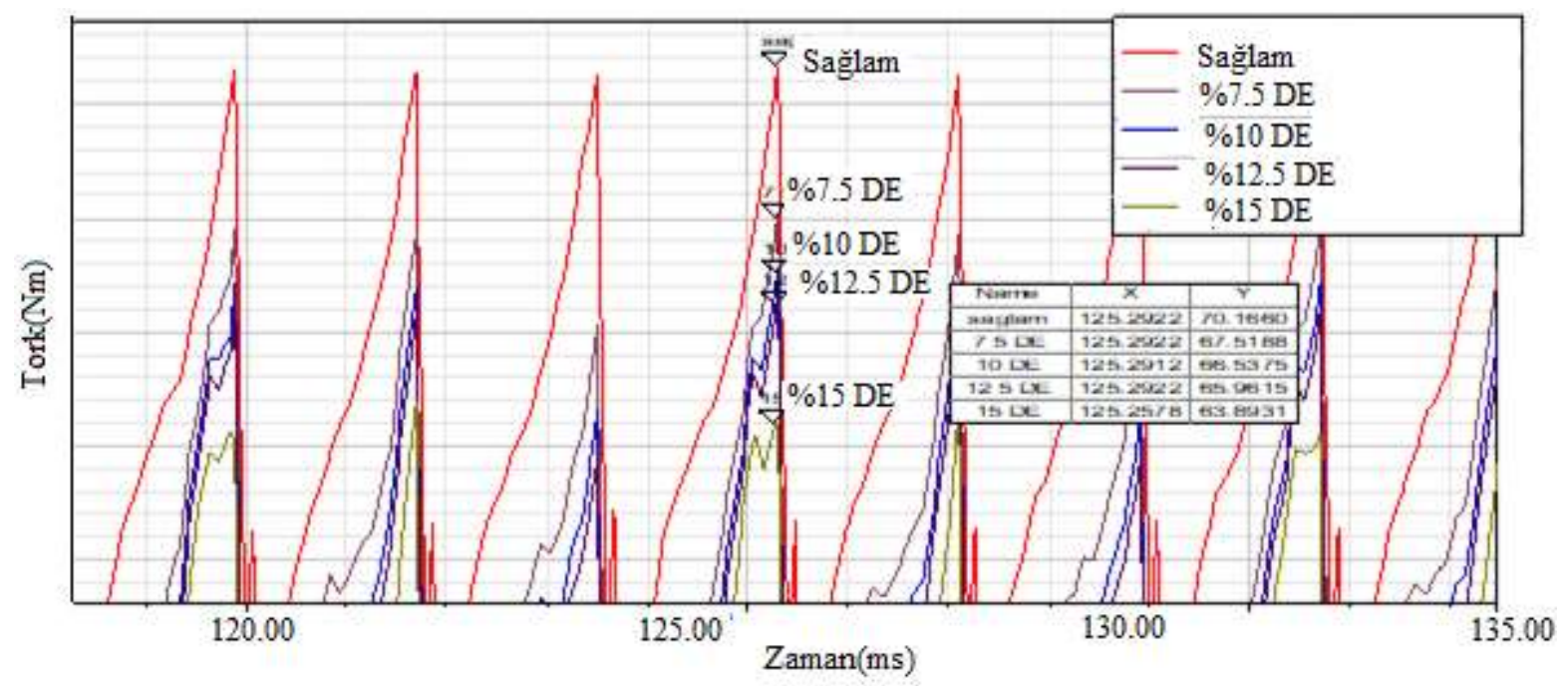

Şekil 6. Çözünürlüğü artırılmış farklı DE şiddetlerinin üst üste bindirilmiş tork dalga formları

Şekil 6'da eksantrikliğin stator akımlarını bozduğu görülüyor. Arıza şiddeti artıkça motorun çektiği maksimum akımda azalma görülürken akım sinyalinde parazitler artmaktadır. Bu bozulma, stator 
akımı spektrumunda, özellik çıkarma ve desen tanıma için kullanılabilecek belirli yan bant bileşenlerini arttırma ihtiyacinı belirtir.

Tablo 4'te arıza şiddeti artıkça torkta düşüş ve sinyalde salınımlar artmaktadır. Statik eksantriklik dengesiz manyetik çekmeye neden olur ve aşırı yüklenme veya hız durumunda bükülmüş bir rotor şaftı, yatak aşınmasına neden olur ve artan arıza şiddeti ile rotorun statora sürtünmesi ile makinenin parçalanmasına yol açar.

Tablo 2. Farklı şiddetteki DE arızalarının akım ve tork karşılaş̧ııılması

\begin{tabular}{|l|c|c|}
\hline & Max Faz akımı & Max Tork \\
\hline Sağ $l_{1 k} l_{1}$ & $81.4929 \mathrm{~A}$ & $70.1660 \mathrm{Nm}$ \\
\hline \%7.5 DE & $74.2779 \mathrm{~A}$ & $67.5188 \mathrm{Nm}$ \\
\hline$\% 10 \mathrm{DE}$ & $72.0486 \mathrm{~A}$ & $66.5375 \mathrm{Nm}$ \\
\hline$\% 12.5 \mathrm{DE}$ & $70.9513 \mathrm{~A}$ & $65.9615 \mathrm{Nm}$ \\
\hline$\% 15 \mathrm{DE}$ & $67.3762 \mathrm{~A}$ & $63.8931 \mathrm{Nm}$ \\
\hline
\end{tabular}

Statik eksantriklik(SE) durumu için rotor, rotor üzerindeki sabit mıknatıslar ve şaftın stator merkezinden $\mathrm{x}$ ve y yönünde $0.3 \mathrm{~mm}-\% 15,0.2 \mathrm{~mm}-\% 10$ ve $0.15 \mathrm{~mm}-\% 7.5$ kaydırılarak SE arızas1 oluşturulmuştur. Rotorun stator ekseninden ayrılmış ve kendi etrafinda döndürülmesi simüle edilmiş ve stator akım sinyalleri arıza şiddetini tespit etmede kullanılmıştır. Sağlıklı ve arızalı BLDC motorun Şekil 7, Şekil 8 ve Şekil 9'da stator akımı ve tork sinyalleri zaman düzleminde gösterilmiştir. Tablo 5 'te arıza şiddeti artıkça akım ve torkta düşüş meydana gelmekedir.

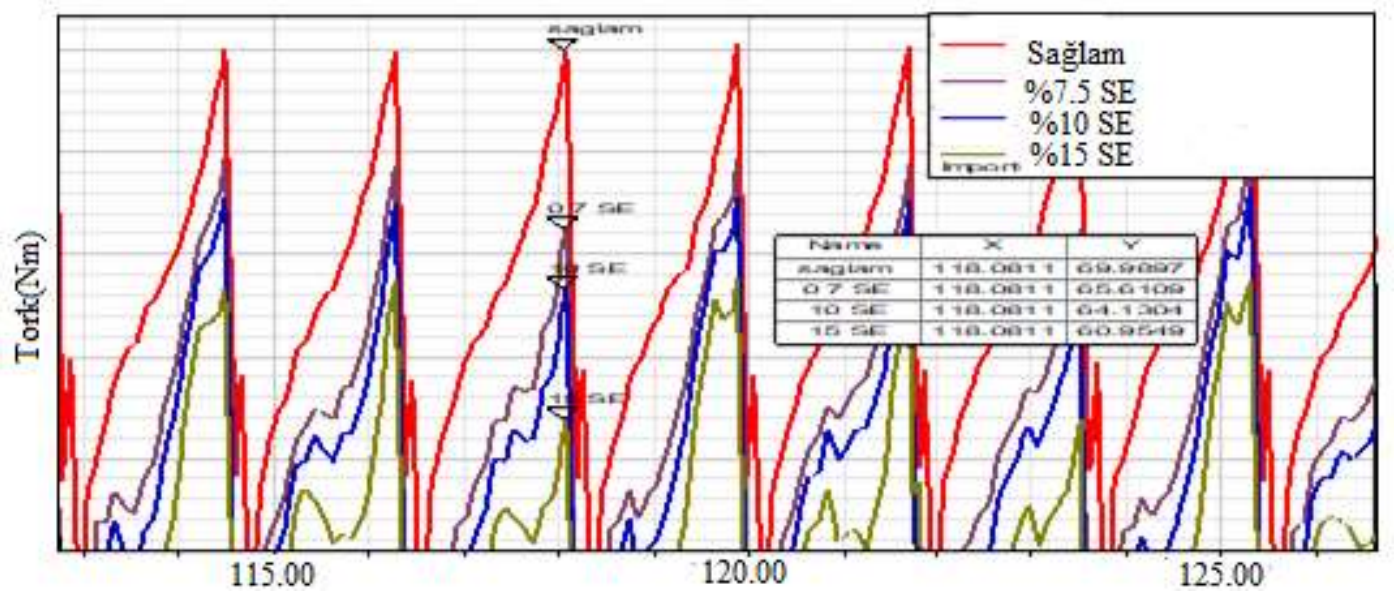

Şekil 7. Çözünürlüğü artırılmış farklı SE şiddetlerinin üst üste bindirilmiş tork dalga formları

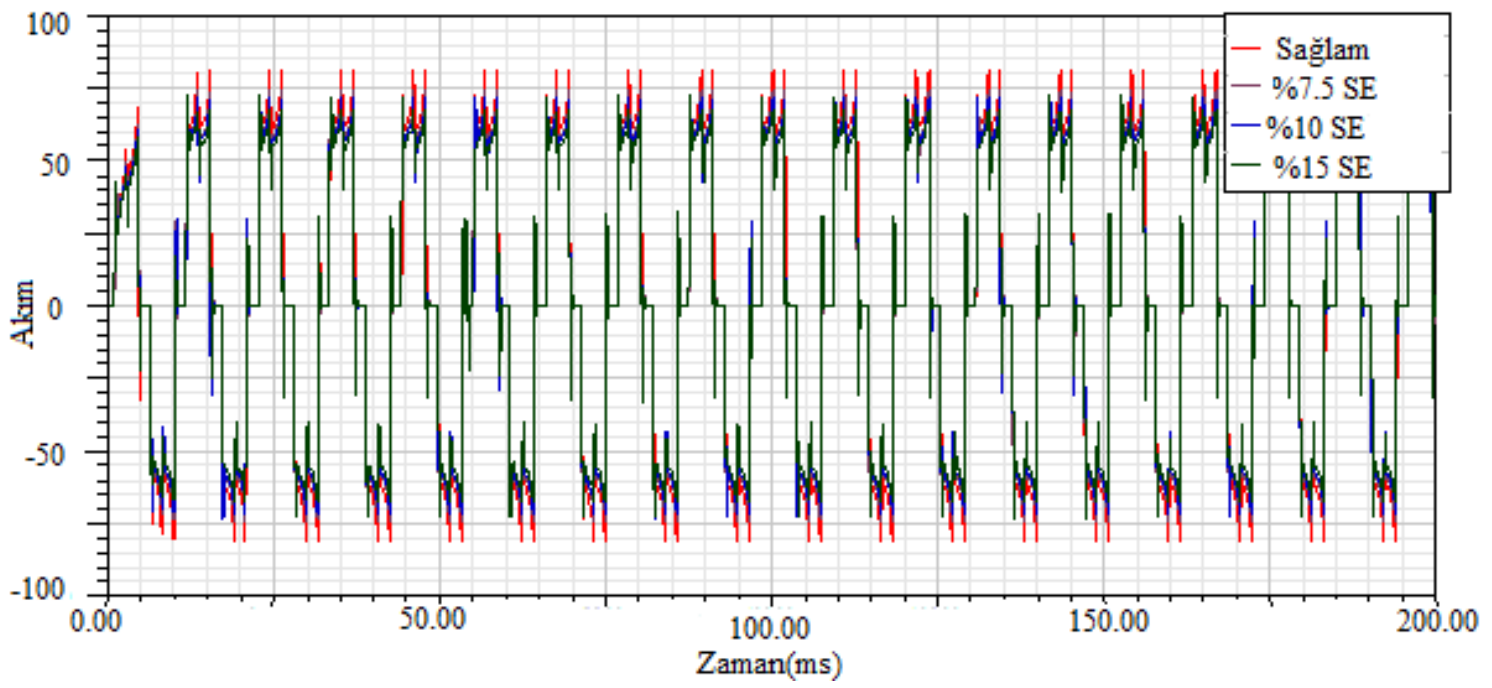

Şekil 8. Farklı SE şiddetlerinin akım dalga formları 


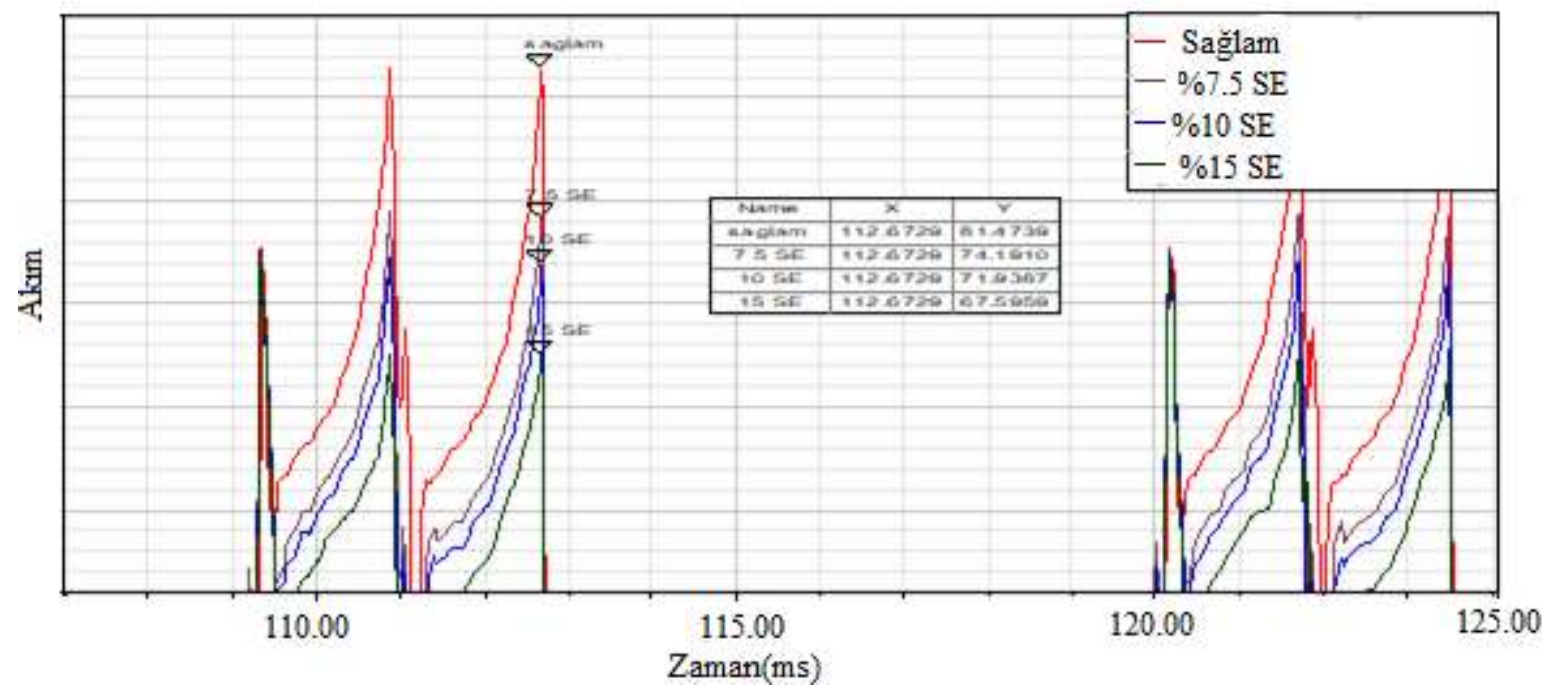

Şekil 9. Çözünürlüğü artırılmış farklı SE şiddetlerinin akım dalga formları

Tablo 3. Farklı şiddetteki SE arızalarının akım ve tork karşıllaştırılması.

\begin{tabular}{|l|c|c|}
\hline & Max Faz Akım & Max Tork \\
\hline Sağliklı motor & $81.4739 \mathrm{~A}$ & $69.990 \mathrm{Nm}$ \\
\hline$\% 7.5 \mathrm{SE}$ & $74.1910 \mathrm{~A}$ & $65.611 \mathrm{Nm}$ \\
\hline$\% 10 \mathrm{SE}$ & $71.9387 \mathrm{~A}$ & $64.131 \mathrm{Nm}$ \\
\hline$\% 15 \mathrm{SE}$ & $67.5959 \mathrm{~A}$ & $60.955 \mathrm{Nm}$ \\
\hline \hline
\end{tabular}

Karışık eksantriklik(KE) arızası oluşturmak için rotor ve rotor üzerindeki sabit mıknatıslar aynı miktarda kaydırılırken şaft stator merkezinden farklı bir miktarda kaydırılmıştır. Bu şekilde rotorun dönme ekseni hem stator ekseninden hem de kendi ekseninden ayrılarak Karışık eksantriklik durumu oluşturulmuştur. Rotor ve rotor üzerindeki sabit miknatıslar orijinden x ve y yönünde $0.3 \mathrm{~mm}$ kaydırıldıktan sonra şaftın merkezi de orijinden $0.2 \mathrm{~mm}$ kaydırılmış ve rotorun kaydırma durumu Karışık Eksantriklik arızası şiddeti olarak referans alınmıştır. Bu yaklaşım ele alınarak farklı şiddetlerde 3 hibrit arıza durumu oluşturulmuştur. Sağlıklı ve arızalı BLDC motorun Şekil 10, Şekil 11 ve Şekil 13 'de stator akımı ve tork sinyalleri zaman düzleminde gösterilmiştir. Şekil 12' de bir faza ait akım dalga formu verilmiştir. Tablo 6’te arıza şiddeti artıkça akım ve torkta düşüş meydana gelmektedir.

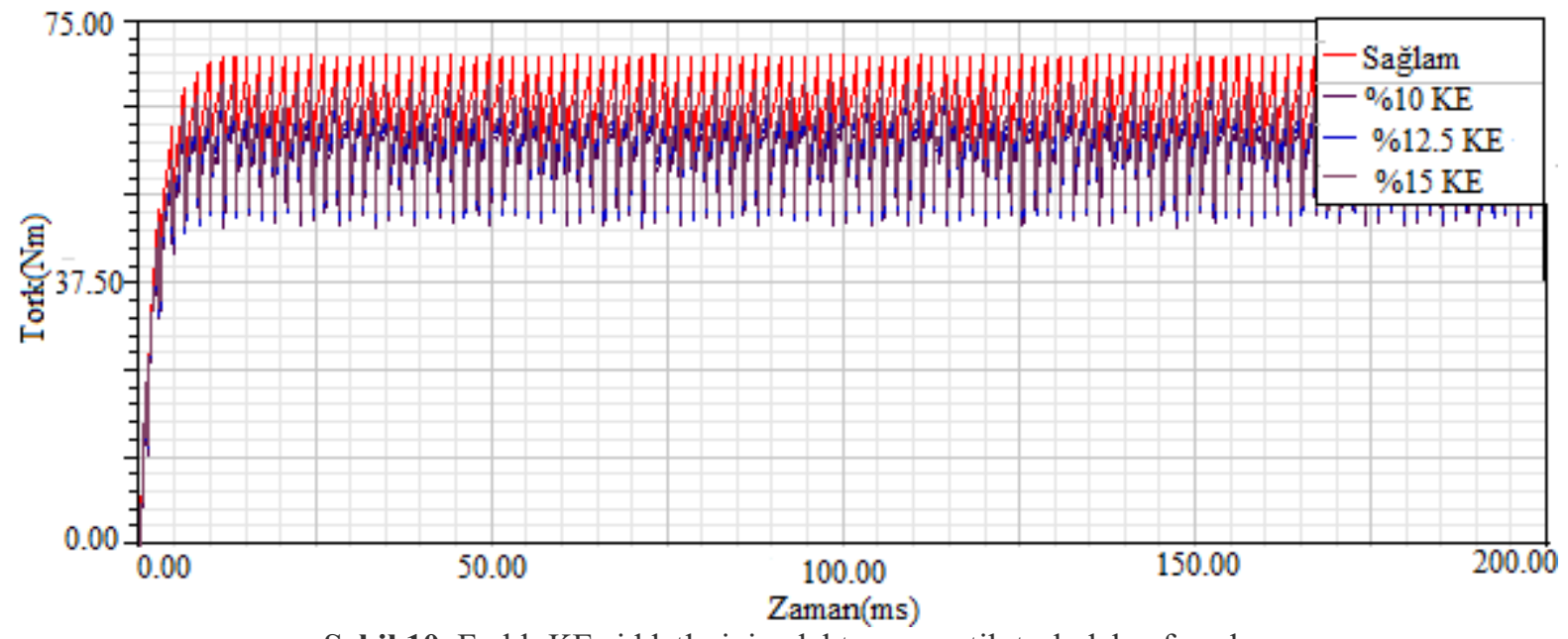

Şekil 10. Farklı KE şiddetlerinin elektromanyetik tork dalga formları 


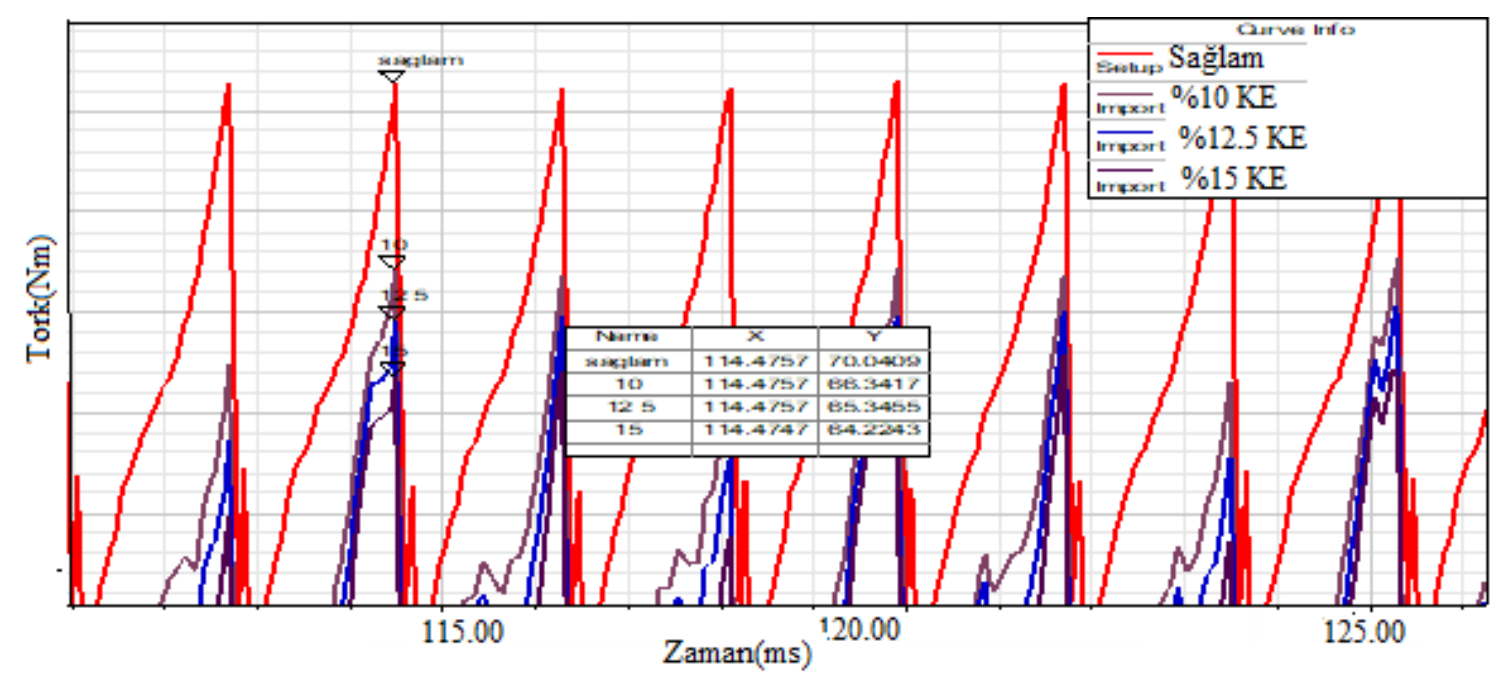

Şekil 11. Çözünürlüğü artırılmış farklı KE şiddetlerinin elektromanyetik tork dalga formları

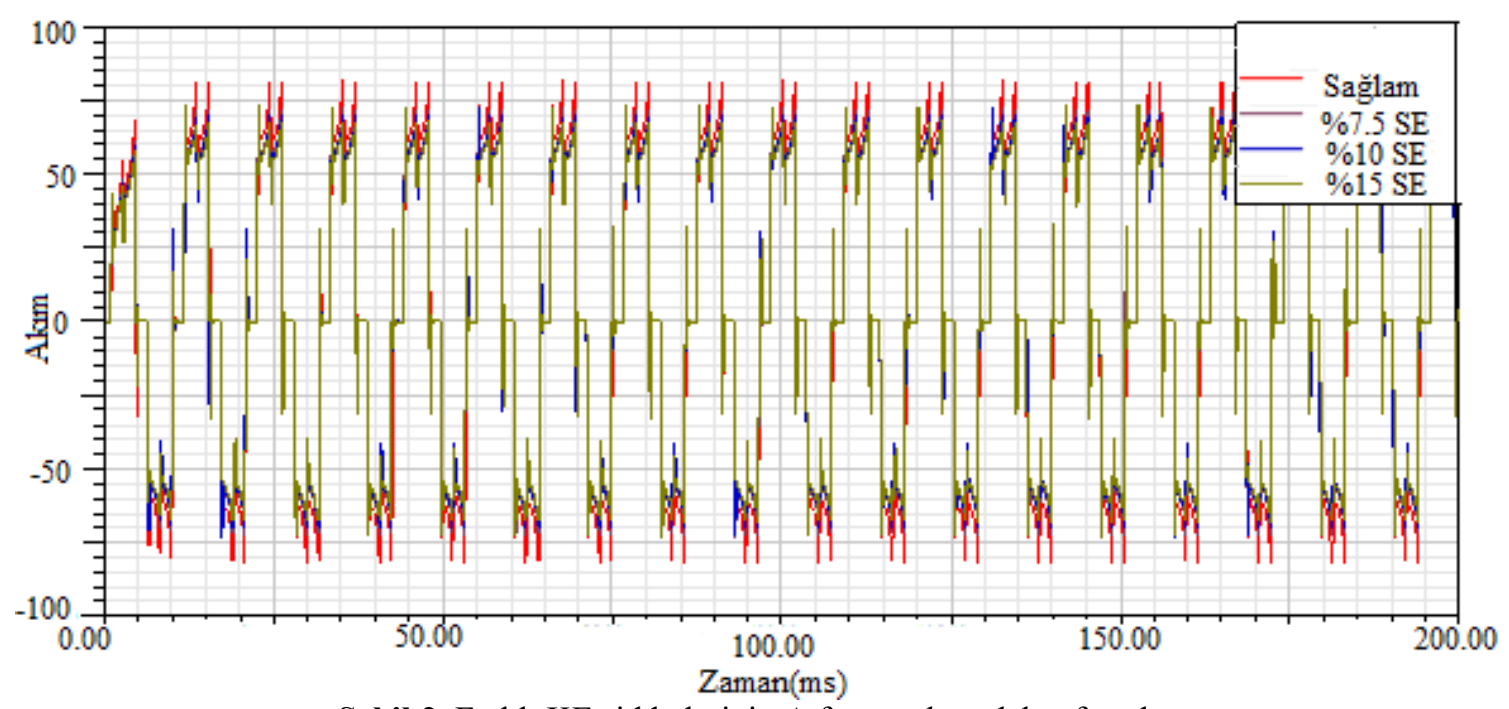

Şekil 2. Farklı KE şiddetlerinin A fazına akım dalga formları

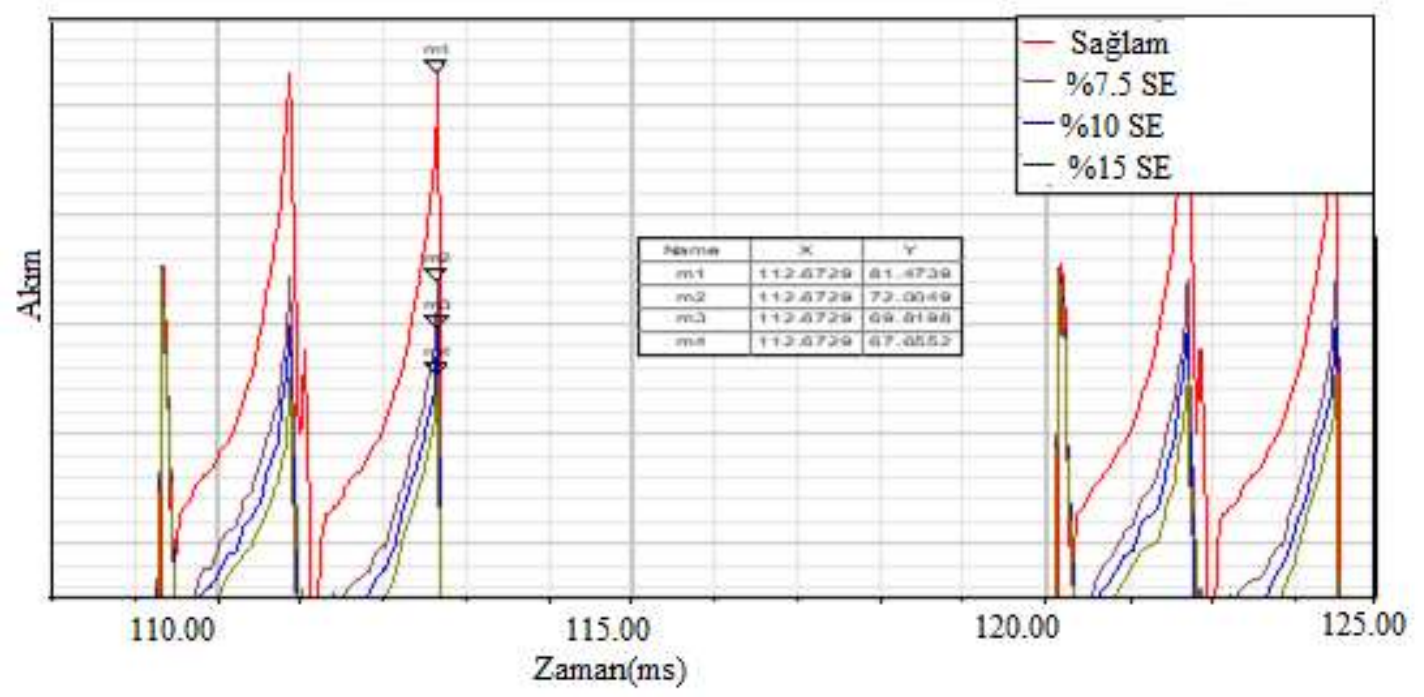

Şekil 13. Çözünürlüğü artırılmış farklı KE şiddetlerinin akım dalga formları 
Tablo 4. Farklı şiddetteki KE arızalarının akım ve tork karşılaştırılması

\begin{tabular}{|l|c|c|}
\hline & Max Faz Akım & Max Tork \\
\hline Sağlıklı motor & $81.4739 \mathrm{~A}$ & $70.049 \mathrm{Nm}$ \\
\hline$\% 10 \mathrm{KE}$ & $72.0049 \mathrm{~A}$ & $66.342 \mathrm{Nm}$ \\
\hline$\% 12.5 \mathrm{KE}$ & $69.8198 \mathrm{~A}$ & $65.346 \mathrm{Nm}$ \\
\hline$\% 15 \mathrm{KE}$ & $67.6552 \mathrm{~A}$ & $64.224 \mathrm{Nm}$ \\
\hline \hline
\end{tabular}

Makinenin mevcut imzasının (MCSA) analizi ile dönen elektrikli makinelerin hata teşhisi, hızlı bir şekilde uygulanmasının basitliği ile kısmen de olsa açıklanabilen yaygın bir yayılma tanı yöntemidir. Donanım tarafında, sadece tek bir faz akımına sensör bağlanarak verileri çevrimiçi alarak anlık arıza tespiti yapılabilir. Yazılım tarafında, karakteristik hata harmonikleri arayışında akımın güç spektrumunu oluşturmak için basit bir hızlı Fourier dönüşümü (FFT) gereklidir [26]. Elektrikli makinelerde durağan olmayan terminoloji, makineden alınan sinyallerin kararlı bir rejime uymadığı anlamına gelir. Temel olarak, çoğu endüstriyel uygulamada sabit koşullar yoktur ve makine çalışma noktası zamana göre değişmektedir. Böyle bir durumda, makinenin sağlık izlemesi zorlukla karşı karşıyadır ve Fourier dönüşümü de dahil olmak üzere geleneksel yöntemlerin uygulanması mümkün değildir. Bu nedenle, daha gelişmiş bir sinyal işleme tekniği uygulanmalıdır. Ancak mevcut çalışmada farklı arıza şiddetlerine bağlı durağan sinyallerdeki (tam yüklenme ve sabit hızda) frekans desenleri, Fourier dönüşümü (FFT) kullanarak bir zaman bölgesi stator akımını kendi frekans alanına dönüştürerek basit bir şekilde analiz edildi.

Tablo 5. Kırık mıknatıs arıza şiddetinin özellik çıkarımında tespit edilen bazı önemli harmonikler

\begin{tabular}{|c|c|c|c|c|c|}
\hline \multirow{2}{*}{$\begin{array}{c}\text { Hamonik } \\
(f s)\end{array}$} & Saglam & \% 3 krkmknts & \% 6krkmknts & \% 9 krkmknts & \% 12 krkmknts \\
\cline { 2 - 6 } & dB(PhaseA) & dB(PhaseA) & dB(PhaseA) & dB(PhaseA) & dB(PhaseA) \\
\hline 1 & 37.63409 & 37.68223 & 37.71769 & 37.78705 & 37.90870 \\
\hline 9 & 18.07241 & 18.05822 & 17.59421 & 17.45461 & 16.94380 \\
\hline 13 & 6.63680 & 6.99389 & 9.16398 & 9.73410 & 9.49331 \\
\hline 15 & 1.04360 & 0.89620 & 2.00004 & 3.97060 & 5.35921 \\
\hline 23 & 0.85398 & 1.06582 & -2.75985 & -6.28480 & -7.62827 \\
\hline 25 & -0.69058 & -1.10809 & -6.62236 & -7.63917 & -10.71415 \\
\hline 29 & 3.73998 & 3.61121 & 3.68351 & 4.60502 & 7.21849 \\
\hline \hline
\end{tabular}

Tablo 7'de temel frekansların katlarındaki karakteristik frekansların, farklı genliklere sahip olduğu açıkça görülmektedir. Makinede arıza varlığını tanımanıza izin verir.

Tablo 6. DE arıza şiddetinin özellik çıkarımında tespit edilen bazı önemli harmonikler

\begin{tabular}{|c|c|c|c|c|c|}
\hline \multirow{2}{*}{$\begin{array}{c}\text { Hamonik } \\
(f s)\end{array}$} & Sağlam & \% 7. 5 DE & \% 10 DE & \% 12.5 DE & \%15 DE \\
\cline { 2 - 6 } & dB(PhaseA) & dB(PhaseA) & dB(PhaseA) & dB(PhaseA) & dB(PhaseA) \\
\hline 1 & 37.63409 & 36.96167 & 36.76888 & 36.66880 & 36.44040 \\
\hline 5 & -1.55227 & -5.96243 & -4.49237 & -4.22521 & -3.06135 \\
\hline 7 & 12.54919 & 11.93656 & 11.74017 & 11.53151 & 10.95163 \\
\hline 11 & 18.05019 & 18.80336 & 18.69438 & 18.63302 & 16.45881 \\
\hline 13 & 6.63680 & 6.25865 & 6.08574 & 5.98690 & 4.34654 \\
\hline 21 & 9.04931 & 10.52937 & 9.91744 & 9.68501 & 9.08026 \\
\hline 23 & 0.85398 & 0.06327 & -0.19292 & -0.70989 & -1.45286 \\
\hline \hline
\end{tabular}

Tablo 8'de sağlam ve DE arızalı makinanın bazı harmonikleri verilmiştir. Dengeli bir yıldız bağlı üç fazlı sistemde, harmonik akımlar, karşılık gelen voltaj bileşen genlikleri, faz açıları veya her ikisi de birbirlerinden farklı olduğu sürece, iki sargı boyunca akar. Bu gerçek, farklı hata durumlarında küçük spektrum varyasyonunu açıklamaya yardımcı olur [27]. 
Tablo 7. SE arıza şiddetinin özellik çıkarımında tespit edilen bazı önemli harmonikler

\begin{tabular}{|c|c|c|c|c|}
\hline \multirow{2}{*}{$\begin{array}{c}\text { Hamonik } \\
(f s)\end{array}$} & Sağlam & \%7 5 SE & \%10 SE & \%15 SE \\
\cline { 2 - 5 } & dB(PhaseA) & dB(PhaseA) & dB(PhaseA) & dB(PhaseA) \\
\hline 1 & 37.63409 & 36.96672 & 36.77481 & 36.43799 \\
\hline 3 & 19.54223 & 19.19255 & 19.05664 & 18.68863 \\
\hline 5 & -1.55227 & -6.01335 & -4.46519 & -0.64117 \\
\hline 15 & 1.04360 & 1.25173 & 1.65945 & 2.34107 \\
\hline 17 & 3.97421 & 3.49800 & 3.24692 & 1.41602 \\
\hline 21 & 9.04931 & 10.52549 & 9.92728 & 9.03876 \\
\hline 29 & 3.73998 & 4.04164 & 3.75432 & 2.82785 \\
\hline 35 & -13.42681 & -22.47667 & -19.22480 & -7.02883 \\
\hline \hline
\end{tabular}

Tablo 9'da statik eksantrikiğe ait özellik çıkarımında kullanılacak bazı önemli harmonikler verilmiştir. Tablo 10'da görüldüğü gibi SE arızasının şiddeti artıkça $1 f s, 3 f s, 15 f s$ ve $17 f s$ de lineer değişimler mevcuttur. Ve bunun yanında $5 f s, 21 f s, 29 f s, 35 f s$ gibi harmonikler de ise arız şiddeti değişimine göre genlik değişimlerinde lineer bir değişim mevcut olmasına rağmen sağlıklı motor durumu ile karşılaştırıldığında özellik çıkarımı için uygun bir değişim görülmemiştir.

Bir özellik, ayırt edici bir özelliği, tanınabilir bir ölçümü ve bir desenin bir bölümünden elde edilen fonksiyonel bir bileșeni temsil eder. Tablo 7, Tablo 8, Tablo 9 ve Tablo 10'de sinyallerle ilgili önemli özellikleri göstermek için RMS, Varyans, Ortalama, Standart Sapma vb. gibi farklı istatistiksel özellikler kullanılabilir. Bu özellikler, farklı patenleri veya motor arızalarını etkili bir şekilde sınıflandırmak için kullanılabilir. Uygun sinyal işleme aracını kullanarak bir sinyalden bilgi edinmek, ardından uygun veri madenciliği tekniği, motor durumunu doğru şekilde belirtmek için hayati bir rol oynar [18].

Tablo 8. KE arıza şiddetinin özellik çıkarımında tespit edilen bazı önemli harmonikler

\begin{tabular}{|c|c|c|c|c|}
\hline \multirow{2}{*}{ Hamonik $(f s)$} & Sağlam & \%10 KE & \%12.5 KE & \%15 KE \\
\cline { 2 - 5 } & dB(PhaseA) & dB(PhaseA) & dB(PhaseA) & dB(PhaseA) \\
\hline 1 & 37.63409 & 36.77215 & 36.57871 & 36.46322 \\
\hline 3 & 19.54223 & 19.07534 & 18.88000 & 18.54825 \\
\hline 5 & -1.55227 & -4.50549 & -3.95611 & -2.35509 \\
\hline 11 & 18.05019 & 18.69515 & 18.57030 & 18.40299 \\
\hline 13 & 6.63680 & 6.08236 & 5.80705 & 4.58247 \\
\hline 21 & 9.04931 & 9.93436 & 9.44662 & 7.64368 \\
\hline 25 & -0.69058 & -1.22763 & -1.31374 & -6.00947 \\
\hline \hline
\end{tabular}

Tablo 9. Eksantriklik arızasında sınıflandırma yöntemlerinin karşılaştırılması

\begin{tabular}{|c|c|c|c|}
\hline $\begin{array}{l}\text { Eksantriklik Arızası } \\
\text { Sinıflandırma } \\
\text { Özeti }\end{array}$ & $\begin{array}{l}\mathrm{k} \\
\mathrm{N} \\
\mathrm{N}\end{array}$ & $\begin{array}{l}\mathrm{M} \\
\mathrm{L} \\
\mathrm{P}\end{array}$ & $\begin{array}{l}\mathrm{R} \\
\mathrm{T}\end{array}$ \\
\hline Doğruluk Yüzdesi (\%) & 100 & 72.7 & 100 \\
\hline Kappaİstatistiği & 1 & 0.7 & 1 \\
\hline Ortalama Mutlak Hata & 0.08 & 0.06 & 0 \\
\hline Kök Ort. Kare Hatası & 0.14 & 0.16 & 0 \\
\hline Göreceli Mutlak Hata(\%) & 50 & 38.9 & 0 \\
\hline Kök Bağ. Kare Hatası(\%) & 50 & 56.5 & 0 \\
\hline Doğru Sınıflandırılmış Örnekler & 11 & 8 & 11 \\
\hline
\end{tabular}


Tablo 10. Demagnetizasyon arızasında sınıflandırma yöntemlerinin karşılaştırılması

\begin{tabular}{|c|c|c|c|}
\hline $\begin{array}{c}\text { Kırık mıknatıs Arızası } \\
\text { Sınıflandırma } \\
\text { Özeti }\end{array}$ & $\begin{array}{l}\mathrm{k} \\
\mathrm{N} \\
\mathrm{N}\end{array}$ & $\begin{array}{l}\mathrm{M} \\
\mathrm{L} \\
\mathrm{P}\end{array}$ & $\begin{array}{l}\mathrm{R} \\
\mathrm{T}\end{array}$ \\
\hline Doğruluk Yüzdesi (\%) & 100 & 100 & 100 \\
\hline Kappa İstatistiği & 1 & 1 & 1 \\
\hline Ortalama Mutlak Hata & 0.16 & 0.2 & 0 \\
\hline Kök Ort. Kare Hatası & 0.2 & 0.2 & 0 \\
\hline Göreceli Mutlak Hata(\%) & 50 & 5.6 & 0 \\
\hline Kök Bağ. Kare Hatası(\%) & 50 & 5.7 & 0 \\
\hline Doğru Sınıflandırılmış Örnekler & 5 & 5 & 5 \\
\hline
\end{tabular}

Hata frekansı bileşenlerinin büyüklüğü genellikle mıknatıs kusur alanının boyutu genişledikçe artar. Arızaya bağlı bu harmonik hava akımı akışları, stator akımında veya voltaj dalga formlarında aynı harmonik bileşenleri üretecektir, çünkü harmonik akışlar statora göre hareket etmektedir. Bununla birlikte, demagnetizasyon arıza tespiti açısından, aynı ek frekanslara sahip olabilecek dinamik eksantriklik ve dengesiz yük gibi arızaları Tablo 12'de görüldüğü gibi ayırt etmek zordur. Tablo 11'de eksantriklik arızasında sinıflandırmasında ve Tablo 13'te BLDC motorunda arıza sinıflandırma k-NN ve RT başarısı daha yüksektir.

Tablo 11. BLDC motorunda arıza sınıflandırma yöntemlerinin karşılaştırılması

\begin{tabular}{l|ccc|}
\hline \multicolumn{1}{c}{ BLDC Motor Arıza Tespiti } & $\mathrm{k}$ & $\mathrm{M}$ & $\mathrm{R}$ \\
\multicolumn{1}{c}{$\begin{array}{c}\text { Sınıflandırma } \\
\text { Özeti }\end{array}$} & $\mathrm{N}$ & $\mathrm{L}$ & $\mathrm{T}$ \\
\hline Doğruluk Yüzdesi (\%) & $\mathrm{N}$ & $\mathrm{P}$ & \\
Kappa İstatistiği & 100 & 80 & 100 \\
Ortalama Mutlak Hata & 0.06 & 0.8 & 1 \\
Kök Ort. Kare Hatası & 0.12 & 0.13 & 0 \\
Göreceli Mutlak Hata(\%) & 50 & 33.8 & 0 \\
Kök Bağ. Kare Hatası(\%) & 50 & 50.4 & 0 \\
Doğru Sınıflandırılmış Örnekler & 15 & 12 & 15
\end{tabular}

\section{Sonuç ve Öneriler}

Bu çalışmada, vektör kontrollü BLDC motorda sürekli mıknatısta oluşan kusurlar ve statik eksantriklik arızası teşhisi yapılmıştır. Bu çalışmada, sonlu elemanlar yöntemiyle hesaplanan manyetik alan, sürücü ve kontrol sistemi ile zayıf bir şekilde birleştirilmiştir. Bu makale daha az belirgin olmayan durumu analiz etmiş ve Fourier ve dalgacık sonuçlarının ölçülenler ile iyi bir uyum içinde olduğunu göstermiştir. Bu çalışmada kullanılan yöntem stator akımı ve stator geriliminin BLDC'nin arıza tespiti için yararlı olduğunu göstermiştir. Ayrıca, farklı sınıflandırıcılar kullanarak karşılaştırmalı bir çalışma da yapılmıştır. k-NN, MLP ve RT incelenen çoklu hataların sınıflandırma doğruluğunun oldukça kayda değer olduğu bulunmuştur.

Çalışmanın genelleştirilmesi açısından, elektrik makinaları bakım programları ve eğilim analizleri üretmek için alt sistemin ve genel stator sinyallerinin daha fazla işlenmesini kolaylaştırmak için ana teşhis modülüne iletişimsel olarak bağlanacak şekilde adapte edilmiş bir merkezi terminal sistemi oldukça etkili olacaktır. Bu merkezi kontrol sistemi makine çalışmasının devamlılı̆̆ı, bakım maliyetlerinin azaltılması, beklenmedik felaket arızalarından kaçınma, iş gücünden ve zamandan kazanç açısından oldukça önemlidir. 


\section{Teşekkür}

Bu makalenin yazarı, verilen destekten dolayı Siirt Üniversitesi Özel Elektrik Makine Laboratuvar çalışanlarına teşekkür ederler.

\section{Yazarların Katkısı}

Bu makale tek isimli bir çalışma olup, sorumlu yazarın makalenin tamamında katkısı bulunmaktadır.

\section{Çıkar Çatışması Beyanı}

Yazarlar arasında herhangi bir çıkar çatışması bulunmamaktadır.

\section{Araştırma ve Yayın Etiği Beyanı}

Yapılan çalışmada araştırma ve yayın etiğine uyulmuştur.

\section{Kaynaklar}

[1] Zandi O., Poshtan J. 2019. Fault Diagnosis of Brushless DC Motors Using Built-in Hall Sensors. IEEE Sensors Journal, 19 (28): 8183-8190.

[2] Cira F., Arkan M., Gumus B. 2016. Detection of stator winding inter-turn short circuit faults in permanent magnet synchronous motors and automatic classification of fault severity via a pattern recognition system. J. Electr. Eng. Technol, 11 (2): 416-424.

[3] Cira F. 2017. Sürekli Mıknatıslı Senkron Motorun Stator Kısa Devre Arızasının Tespiti ve Arıza Şiddetinin Otomatik Olarak Belirlenmesi. Doktora Tezi, İnönü Üniversitesi, Fen Bilimleri Enstitüsü, Malatya.

[4] Khan M.S., Okonkwo U.V., Usman A., Rajpurohit B.S. 2018. Finite Element Modeling of Demagnetization Fault in Permanent Magnet Direct Current Motors. In 2018 IEEE Power and Energy Society General Meeting, IEEE, pp. 1-5.

[5] Choi G., Jahns, T.M. 2015. Post-demagnetization characteristics of permanent magnet synchronous machines. In 2015 IEEE Energy Conversion Congress and Exposition(ECCE), IEEE, pp. 17811788.

[6] Polat A., Ergene L.T., Bakhtiarzadeh H. 2018. Asansör Uygulamalarında Kullanılan Daimi Mıknatıslı Senkron Motor Tasarımı. Gazi Üniversitesi Mühendislik-Mimarlık Fakültesi Dergisi, 2018 (2018): 757-770.

[7] Bruzzese C. 2013. Diagnosis of eccentric rotor in synchronous machines by analysis of splitphase currents - Part I: Theoretical analysis. IEEE Transactions on Industrial Electronics, 61 (8): 4193-4205.

[8] Espinosa A.G., Rosero J.A., Cusidó J., Romeral L., Ortega, J.A. 2010. Fault detection by means of Hilbert-Huang transform of the stator current in a PMSM with demagnetization. IEEE Transactions on Energy Conversion, 25 (2): 312-318.

[9] Khan M. A. S. K., Rahman M. A. 2009. Development and Implementation of a Novel Fault Diagnostic and Protection Technique for IPM Motor Drives. IEEE Transactions on Industrial Electronics, 56 (1): 85-92.

[10] Rosero J.A., Romeral L., Cusidó J. Garcia A., Ortega J.A. 2007. On the short-circuiting fault detection in a PMSM by means of stator current transformations. PESC Record - IEEE Annual Power Electronics Specialists Conference, 1936-1941.

[11] Lee Y., Habetler T.G. 2007. An on-line stator turn fault detection method for interior PM synchronous motor drives. Conference Proceedings - IEEE Applied Power Electronics Conference and Exposition - APEC, 825-831.

[12] Ebrahimi B.M., Faiz J. 2010. Feature extraction for short-circuit fault detection in permanentmagnet synchronous motors using stator-current monitoring. IEEE Transactions on Power Electronics, 25 (10): 2673-2682.

[13] Stavrou A., Sedding H.G., Penman J. 2001. Current monitoring for detecting inter-turn short 
circuits in induction motors. IEEE Transactions on Energy Conversion, 16 (1): 32-37.

[14] Silvester P., Chari M.V.K. 1970. Finite Element Solution of Saturable Magnetic Field Problems. IEEE Transactions on Power Apparatus and Systems, 7: 1642-1651.

[15] Salon S.J. 2011. Finite Element Analysis of Electrical Machines. Springer Science \& Business Media.

[16] Witten I.H. , Frank E.H. 2011. Practical Machine Learning Tools and Techniques. United State: Morgan Kauffman.

[17] Panigrahy P.S., Konar P., Chattopadhyay P. 2016. Application of data mining in fault diagnosis of induction motor. 2016 IEEE 1st International Conference on Control, Measurement and Instrumentation (CMI), IEEE, p. 274-278.

[18] Gürbüz F., Turna F. 2018. Rule extraction for tram faults via data mining for safe transportation, Transportation Research Part A: Policy and Practice, 16: 568-579.

[19] Sjökvist S., Eriksson S. 2014. Experimental verification of a simulation model for partial demagnetization of permanent magnets. IEEE Transactions on Magnetics, 50 (12): 1-5.

[20] Chen H., Qu R., Li J., Li D. 2015. Demagnetization Performance of a 7 MW Interior Permanent Magnet Wind Generator with Fractional-Slot Concentrated Windings. IEEE Transactions on Magnetics, 51 (11): 1-4.

[21] Da Y., Shi X., Krishnamurthy M. 2011. Health monitoring, fault diagnosis and failure prognosis techniques for brushless permanent magnet machines. 2011 IEEE Vehicle Power and Propulsion Conference (VPPC), IEEE, pp. 1-7.

[22] Usman A., Joshi B.M., Rajpurohit B.S. 2017. Review of fault modeling methods for permanent magnet synchronous motors and their comparison. Proceedings of the 2017 IEEE 11th International Symposium on Diagnostics for Electrical Machines, Power Electronics and Drives(SDEMPED), IEEE, pp. 141-146.

[23] Mirimani S.M., Vahedi A., Marignetti F., De Santis E. 2012. Static eccentricity fault detection in single-stator-single-rotor axial-flux permanent-magnet machines. IEEE Transactions on Industry Applications, 48 (6): 1838-1845.

[24] Cameron J.R., Thomson W.T., Dow A.B. 1986. Vibration and current monitoring for detecting airgap eccentricity in large induction motors. IEE Proceedings B Electric Power Applications, 133 (3): 155-163.

[25] Kang K., Song J., Kang C., Sung S., Jang G. 2017. Real-Time Detection of the Dynamic Eccentricity in Permanent-Magnet Synchronous Motors by Monitoring Speed and Back EMF Induced in an Additional Winding. IEEE Transactions on Industrial Electronics, 64 (9): 7191 7200 .

[26] Sapena-Bañó A., Pineda-Sanchez M., Puche-Panadero R., Martinez-Roman J., Matić D. 2015. Fault Diagnosis of Rotating Electrical Machines in Transient Regime Using a Single Stator Current's FFT. IEEE Transactions on Instrumentation and Measurement, 64 (11): 3137-3146.

[27] Goktas T., Zafarani M., Akin B. 2016. Discernment of Broken Magnet and Static Eccentricity Faults in Permanent Magnet Synchronous Motors. IEEE Transactions on Energy Conversion, 31 (2): $578-587$. 